Article

\title{
A Survey of the Japanese Influence on Buddhist Education in Taiwan during the Japanese Colonial Period (1895-1945)
}

\author{
Pei-ying Lin \\ Department of Religious Studies, Fu Jen Catholic University, New Taipei City 24205, Taiwan; \\ 134921@mail.fju.edu.tw
}

Received: 5 December 2019; Accepted: 23 January 2020; Published: 28 January 2020

\begin{abstract}
This paper analyses the Japanese influence upon Taiwanese Buddhist communities during the Colonial Period. I will discuss the interplay between monasticism, education, and politics by examining the process of institutionalisation of monastics and Buddhist educational programs in Taiwan between 1895 and 1945. In accord with pertinent historical developments, this paper is divided into five sections: (1) the Sōtō Zen lineage, (2) the Rinzai Zen lineage, (3) the Pure Land (Jōdo) lineage, (4) Taiwanese monastics who studied in Japan, and (5) Taiwanese nuns. Based on the strong Japanese sectarian tradition, different sects had disparate strategies in Taiwan. The Sōtō lineage arrived first, engaged in precept ceremonies, and started up a well-run Buddhist college. The Myōshinji Sect of Rinzai took Kaiyuansi in Tainan as the main headquarters in southern Taiwan for teaching Buddhist classes as well as holding monumental precept-conferral ceremonies. As for the Pure Land lineage, they came slightly later but eventually established 37 branches across Taiwan, implementing social-educational programs actively. Finally, the nuns and monks who went abroad to study Buddhism in Japan matured and took important roles in advancing Buddhist education in Taiwan. All of these cases demonstrate a profound Japanese influence upon Taiwanese Buddhist education and monastic culture.
\end{abstract}

Keywords: Buddhist education; Taiwanese Buddhism; Japanese occupation of Taiwan (1895-1945); monasticism; modern Buddhism

\section{Introduction ${ }^{1}$}

The 20th century saw important changes and immense struggles in Chinese Buddhism. In facing the global movement of modernisation in the twentieth century, Chinese Buddhists experienced unforeseen challenges and called for certain drastic reforms. In this period, at the turn of the twentieth century, Master Taixu (1890-1947) was one of the most representative figures of Chinese Buddhism. Thanks to ground-breaking works by Holmes Welch, we have gained a firm foundation of background knowledge for this period (Welch 1967, 1968, 1972). Following his work, there have been bountiful studies on the life and influence of Taixu (Rintzinger 2017; Goodell 2008; Hou 2018), as well as those on a broader context of modern Chinese Buddhism (Birnbaum 2007; Chen and Deng 2003; Hammerstrom 2015; Ji 2015; Ji and Liddell 2005).

How Taiwanese Buddhism transformed into a modern religion is a story that differs from the one for China. The features of Taiwanese Buddhism include, for example, nuns' remarkable achievement in

1 The author thanks peer reviewers for their perceptive comments and Robban Toleno for his English editing suggestions. Meanwhile, special thanks go to He Yansheng and Yen Wei-Hung for their informative knowledge of Japanese scholarship. 
the 21st century and the flourishing of Buddhist NGOs in Taiwan, such as the Ciji (Tsu Chi) Foundation. ${ }^{2}$ This is because Taiwan went through turbulent periods under the rule of the Japanese colony and the Nationalist Party, successively. It is difficult to make an overarching statement of the development of Taiwanese Buddhism without considering the different historical periods. The period of Japanese occupation, in particular, situated between the major shift from late imperial China and the modern period, prepared Taiwan for significant Buddhist reforms afterward, and hence was a crucial stage in Taiwanese Buddhism.

There are ample topical studies on the history of Taiwanese Buddhism during the Japanese colonial period, as well as on various aspects of the interaction between social-political situations and Taiwanese religions (Jiang 2001; Jones 1999; Kan 1999; Kan 2014a; Li 1999; Li 2016; Minowa 2003; Minowa 2006; Nakanishi 2016; H. Shi 1999; Shi 2008; Tainaka 2008; Wang 1999a; Washimi 1985; Wen 1999; Yan 2008). ${ }^{3}$ The current paper is built on previous scholarship and further develops the inquiry concerning modernity, to be precise, its impact on two important aspects of Buddhism: monasticism and monastic education. Both Japanese and Taiwanese Buddhists initiated changes and reforms in modern Buddhist education in Taiwan during the colonial period. Japanese Zen lineages, especially Sōtō 曹洞 and Rinzai 臨濟, are good examples for seeing how different Japanese models of monasticism departed from a premodern Chinese model. Moreover, the Japanese Pure Land lineage, especially Jōdo shinshū 淨土真宗, reformed and adapted itself into a modern chaplaincy model (Payne and Tanaka 2004). The Zen and Pure Land communities tend to adopt different approaches to their monasticism and monastic education, and so did their branches in Taiwan. All of these lineages established educational institutions for monastics, as well as lay educational programs given by monastics. Both models enhanced lay-monastic ties in Buddhist education in Taiwan. Along these lines, this paper analyses the Japanese influence upon Taiwanese Buddhist education during the Colonial Period. I will discuss the interplay between monasticism, Buddhist communities, and politics by examining the process of institutionalisation of monastics and Buddhist educational programs in Taiwan between 1895 and 1945. Based upon pertinent historical developments, this paper is divided into five sections: (1) the Sōtō lineage, (2) the Rinzai lineage, (3) the Pure Land lineage, (4) Taiwanese monastics who studied in Japan, and (5) Taiwanese nuns.

\section{The Historical Backdrop}

After the Treaty of Shimonoseki was signed in 1895 C.E., the Japanese government took over Taiwan and began a 50-year colonial rule. When Japanese Buddhist priests arrived at Taiwan with the Japanese army, they started to divide up areas for establishing Buddhist institutions and absorbed local Taiwanese Buddhist communities as branches of their Japanese home temples. During this period, religious policy of the Japanese Government-General (Sōtoku-fu 總督府) changed in 1915 and 1937 respectively as the following sections will explain. ${ }^{4}$

\subsection{Establishment of the South Seas Buddhist Association (SSBA)}

The change of policy in 1915 was a result of the Xilai'an 西來庵 Incident. Yu Qingfang 余 清芳 of the Xilai Temple in Tainan stirred the crowd up with his slogan of establishing a "Great Ming Compassionate Kingdom" (Daming cibeiguo 大明慈悲國) in order to attack Japanese soldiers. Approximately 1957 people were arrested and around 900 people received the death penalty. After this

2 For instance, see Julia Huang's case study of the Ciji Foundation, a unique NGO under the charismatic female leadership of Venerable Zhengyan 證嚴法師. (Huang 2009). Also, Richard Madsen has argued for a highly positive correlation between the development of a democratic scheme and major Taiwanese Buddhist associations, including Dharma Drum Mountain 法 鼓山, Foguang Shan, Ciji, etc. (Madsen 2007).

3 Furthermore, scholars, such as Paul Katz, Philip Clart, Julian Pas, Christian Jochim, Barbara Reed, André Laliberté, Murray Rubinstein, Zhang Xun 張珣, and Li Fengmao 李豐惁, have discussed various aspects of the interaction between social-political situations and Taiwanese religions. See (Clart and Jones 2003).

4 For a balanced, general historical survey, see (Jones 1999). 
incident, Japanese governors turned from a previously impartial attitude towards Taiwanese religious practitioners to actively engaging them.

After that time, the Japanese government began to reinforce colonization, beginning with frequent religious investigations. These investigations were conducted by the Minister of Religion (Shajika cho 社寺課長) Marui Keichirō 丸井圭智郎 (1870-1934). At the same time, Japanese governors encouraged Taiwanese Buddhist groups to formulate the South Seas Buddhist Association (SSBA, Ch. Nanying fojiaohui, Jp. Nanei bukkyōkai 南瀛佛教會) to enhance mutual communications. Moreover, the Japanese government assisted Zhaijiao members in establishing the "Longhua Buddhist Community of Taiwan" (Taiwan fojiao longhua hui 台灣佛教龍華會) so as to enhance official control over the Zhaijiao 齋教. ${ }^{5}$ The South Seas Buddhist Association had made tremendous efforts to remove any "superstitious" activities, according to their standards, and to improve the Buddhist knowledge of Taiwanese. Buddhist forums were held frequently. There were 19 events organised by the South Seas Buddhist Association between 1921 (Taishō 12) and 1936 (Shōwa 11). We have records of the following SSBA events in Table 1:6

Table 1. List of SSBA Lectures (1921-1936).

\begin{tabular}{|c|c|c|c|c|}
\hline & Common era & Japanese Calendar & Organisation & City/County \\
\hline 1 & 1919 & Taishō 10 & Sōtō's Taiwan Buddhist Middle School & Taipei \\
\hline 2 & 1919 & Taishō 10 & Kaiyuan Temple 開元寺 & Tainan \\
\hline 3 & 1920 & Taishō 11 & Shenzhaitang 慎齋堂 & $\begin{array}{l}\text { Taizhong } \\
\text { (Taichung) }\end{array}$ \\
\hline 4 & 1920 & Taishō 11 & Sōtō's Taiwan Buddhist Middle School & Taipei \\
\hline 5 & 1921 & Taishō 12 & Yuanshan Linji Temple 臨濟寺 & Taipei \\
\hline 6 & 1921 & Taishō 12 & Guanyin Practice Hall & Miaoli, Xinzhu \\
\hline 7 & 1922 & Taishō 13 & Branch of Banqiao Centre & Taipei \\
\hline 8 & 1926 & Shōwa 1 & Yuanguang Temple 圓光寺 & Zhongli, Xinzhu \\
\hline 9 & 1927 & Shōwa 2 & Shitoushan Shitoudong 獅頭山獅頭洞 & Xinzhu \\
\hline 10 & 1929 & Shōwa 4 & Daxianyan 大仙嘊 & Jiayi \\
\hline 11 & 1930 & Shōwa 5 & Guanyinshan Lingyun Temple 凌雲寺 & Taipei \\
\hline 12 & 1932 & Shōwa 7 & Kaiyuan Temple & Tainan \\
\hline 13 & 1932 & Shōwa 7 & Yuemeishan Lingquan Temple 靈泉寺 & Taipei \\
\hline 14 & 1934 & Shōwa 9 & Neiwei Longquan Chan Temple 龍泉禪寺 & $\begin{array}{l}\text { Gaoxiong } \\
\text { (Kaohsiung) }\end{array}$ \\
\hline 15 & 1934 & Shōwa 9 & Mituo Chan Temple 彌陀禪寺 & Tainan \\
\hline 16 & 1936 & Shōwa 11 & Dongshan Chan Temple 東山禪寺 & Pingdong \\
\hline
\end{tabular}

\subsection{Period of Further Integration}

The second major change in Japanese policy happened after the Marco Polo Bridge Incident in 1937, which triggered the second Sino-Japanese War. Since then, the Kōminka Movement (Japanisation Movement) intensified, and, in the same historical period, the Temple Rectification Movement (Simiao zhengli yundong 寺廟整理運動) began in Taiwan. Folk practices such as burning paper money were abandoned and worshipping activities were under strict inspection. Many temples were either combined with another temple or abolished forcefully. Many of them were absorbed into Japanese Buddhist branches.

During this period, while gaining Japanese support continuously, local Taiwanese communities gradually rose up in five main strands: (1) Lingquansi sect of Mt. Yuemei 月眉山, Jilong (Keelung); (2) Lingyunsi sect of Mt. Guanyin 觀音山, Taipei; (3) Fayunsi 法雲寺 sect of Dahu 大湖, Miaoli; (4) Kaiyuansi sect, Tainan; and (5) Chaofengsi 超峰寺sect of Mt. Dagang 超峰寺, Gaoxiong (Kaohsiung). It must be emphasised that these five sects were affiliated with Japanese temples on the one hand, and,

5 The Zhaijiao, literally "vegetarian religions," referring to a type of popular religion among lay people originating in late imperial China. For an early historical background of this lay religion, see (De Groot; Tsukamoto 1949). For the later development in Taiwan, see (Jiang and Wang 1994).

6 See Nanying fojiao, Vol. 8, No. 6 (1930). The contents of Nanying fojiao in this article are all taken from the Taiwanese Buddhist Digital Database. (http://buddhism.lib.ntu.edu.tw/museum/TAIWAN/) 
on the other hand, observed the tradition of receiving full ordination from Mt. Gu in mainland China. Furthermore, monks from Yongquan Temple 湧泉寺 of Mt. Gu 鼓山, Fujian, visited Taiwan regularly to preach on the precepts. These five Taiwanese sects maintained their alliance with both mainland China and Japan.

The result of such further integration during this period is that Japanese Buddhists had a great impact on Buddhist education in Taiwan. For example, the Lingquan Temple of Mt. Yuemei and Lingyun Temple of Mt. Guanyin became branches of Japanese Sōtō and Rinzai respectively, and the Japanese headquarters enhanced their implementation of education in these branches. Institutionalised education was mainly conducted at "middle schools" (zhongxuelin 中學林), as well as at non-institutionalised forums, seminars, and study groups. All of these became the embryos of later Buddhist educational programs for both the monastics and the laity in Taiwan. The current paper will follow the division of the Japanese sects and analyse the Japanese influence during the Japanese occupation period.

\section{Sōtō Activities in Taiwan}

Among the major Japanese Buddhist sects, the Sōtō lineage was the first to begin Buddhist programs in Taiwan. According to the Sōtōshū kaigai dendōshi 曹洞宗海外開教傳道史，Sasaki Chinryū 佐木珍 (1865-1934) was dispatched by the Bureau of Sōtō Lineage Affairs (Sōtō shūmukyoku 曹洞宗務局) to preach in the Japanese army in Taiwan (Shi 1998). ${ }^{7}$ Compared to most other Japanese monks, Sasaki Chinryū was the first to make efforts in overcoming language barriers: he would arrange interpreters at most Buddhist events, and he later established a language school at the Longshan Temple, Taipei. He then set up sewing schools for women to help them acquire skills and earn their own living. These language schools became models for later Japanese Buddhist institutions. Indeed, the Sōtō lineage was influential for their educational activities for both monastics and the laity during the initial stage of Japanese occupation.

\subsection{The Precept-Conferral Ceremony}

There were many important events held by the Sōtō lineage in Taiwan; the most important ones include establishing a precept-conferral ceremony (Jp. Shilakai, Ch. Shiluohui 尸羅會, shiluo being a transliteration from Sk. sīla, i.e., Buddhist precepts) in Zhanghua in 1898 (Meiji 31). In fact, the Sōtō monks intended to preach in the Japanese army at first, and expected the audience of their Buddhist lectures to be solely Japanese. Gradually they reached out to Taiwanese folks in the countryside. A famous example is Nagata Kanzen 長田觀禪, who preached relentlessly in Zhanghua and eventually set up the precept-conferral ceremony, mentioned above, in 1898 (Shi 2008, p. 302). It is worth mentioning that, during the first three days of the ceremony, there were only around 120-130 participants. Reaching the fourth day, the number of participants increased to 400-500 people, and 84 people eventually received the ordination. It is clear that the ceremony appealed to a great number of local people and elicited their interest in participating in Japanese Buddhist activities.

\subsection{The Taiwan Buddhist Middle School}

After the precept-conferral ceremony took place in 1898, the Sōtō lineage decided to further educate Taiwanese Buddhists and in 1916 (Taishō 5) built the Taiwan Buddhist Middle School (Jp. Taiwan bukkyō chūgakurin, Ch. Taiwan fojiao zhongxue lin 台灣佛教中學林), which attracted remarkable attention from the public. It was initiated in 1915 (Taishō 4) by Ōishi Kendō 大石堅童 (1868-1934), the seventh Director of the Taipei branch of the Sōtō lineage, right after the Xilai'an Temple Incident. The official purpose of establishing this school was to reinforce monastic education in Taiwan and to prevent superstitious beliefs and activities. It gained local support from numerous Buddhist groups in

7 Furthermore, on this Japanese monk's activity in the famous Longshan Temple, see (Kan 2013). 
Taiwan, such as the monks Shanhui 善慧 (1881-1945) and Benyuan 本圓 (1883-1947). At the opening ceremony in 1917 (Taishō 6), Nukariya Kaiten 忽滑谷快天 (1867-1934) was invited as a distinguished guest, which drew much attention in Buddhist circles. During this first visit to Taiwan, Nukariya Kaiten was invited to give lectures on each day of his stay. These lectures inspired many young Buddhists of that time, such as Lin Delin 林德林 (1890-1951), Gao Zhide 高執德 (1896-1955), Zeng Jinglai 曾景來 (1902-1977), and Li Tianchun 李添春 (1899-1988), all of whom became leaders of Taiwanese Buddhism later on. ${ }^{8}$

The Sōtō lineage's Taiwan Buddhist Middle School was a three-year program with an enrollment of 25 students each year, including undergraduate and postgraduate programs. Its first enrollment had half monastic and half secular students; among the monastics, half were Taiwanese and half Japanese. Since the equivalent program in Japan was a five-year program, when students finished their third year, they had an opportunity to enroll in a fourth year at the Sōtō lineage's Tatara Middle School in Yamaguchi prefecture, Japan. Those who performed well could then continue to take their fifth year in the Sōtosshu daigakurin (Komazawa University of the present day). This was a successful model for later educational institutes.

The first president of the Sōtō lineage's Taiwan Buddhist Middle School was Ōishi Kendō, followed by the monk Shanhui, Shimada Kōshū 島田弘舟 (1938-1938), Takata Ryōzō 高田良三（1938-1938), and Kimura Yūzan 木村雄山 (1938-1945), who were all monastics. It was not until the Republican Period that the position of president was offered to people from a secular background, such as Zhuang Minggui 莊名桂 (fl. 1931), Zheng Songxi 鄭松溪 (d.1898), Li Tianchun, and Peng Rongjie 彭榮傑 (fl. 1968). The school eventually became an ordinary private high school. ${ }^{9}$ In the 1940s, the Sōto lineage established the North Training Centre of the Taiwan Buddhist Association (Jp. Taiwan hokubu nenseisho, Ch. Taiwan fojiao beibu liancheng suo 台灣佛教會北部練成所) for monastic education (Zhou 2013, p. 74).

\section{Rinzai Activities in Taiwan}

\subsection{Kaiyuan Temple, Tainan}

Kaiyuan Temple became an important Buddhist hub for southern Taiwan. In 1915 (Taishō 4), the Myōshinji Sect of the Rinzai lineage took Tainan Kaiyuan Temple as its southern headquarters, hosting lectures and conferring Buddhist precepts. Previously, the Tainan Kaiyuan Temple had become a branch of the Sōtō lineage in 1895 before disconnecting in 1915 and joining the Rinzai lineage in the same year. After the Xilai'an Temple Incident happened unexpectedly in 1915, the colonial government changed its religious policy from tolerance to intensive control, and Rinzai monks at the home temple of Myōshinji in Kyoto made a quick new missionary plan for the changing situation in Taiwan. As a result, Hasegawa Jien 長谷慈圓 (1880-1918) and the monk Chuanfang 傳芳 (1855-1918) began to collaborate in handling the new political situation. At their meeting in 1916, they discussed issues including establishing the Zhennan Middle School (Chinnan gakurin 鎮南學林) and arranging a visit to the Myōshinji (Wang 1999a, pp. 371-72). Under the supervision of Hasegawa Jien, the monks Chuanfang, Benyuan, and Chengyuan 成圓 (1890-1933) enthusiastically assisted in construction of the Buddhist school. It was under these circumstances that Kaiyuan Temple disconnected from the Sōtō lineage, joined the Rinzai lineage, and became the major Rinzai centre in southern Taiwan.

Before 1915, relations between the Chinese mainland and Tainan Kaiyuan Temple were firm and persistent. All the abbots received ordination at Mt. Gu, Fujian Province. According to Zeng Jinglai's Kaiyuan chansi jilue (Zeng 1937, p. 41), all previous abbots must have received a full training at the Yongquan Temple at Mt. Gu, Fujian Province, before they were eligible for abbotship. This convention was upheld until the retirement of Abbot Chuanfang in 1915. Chuanfang, the 43rd abbot of

8 For Nukariya Kaiten's impact on Taiwanese Buddhists, see (Shi 2008, pp. 529-48; Ōno 2009, pp. 101-13).

9 This Buddhist Middle School was turned into an ordinary high school in 1935, and was renamed Private Taibei Senior High School in 1947, which it remains to the present day. 
Kaiyuan Temple, came originally from Tainan and had resided at Mt. Gu before he was invited to take the position as Kaiyuan abbot in 1913. The Kaiyuan abbots after Chuanfang included Deyuan 得圓 (1882-1946), Zhengfeng 證峰 (Lin Qiuwu 林秋梧, 1903-1934), and Zhengguang 證光 (Gao Zhide); all of these names were influential and active figures of their time. ${ }^{10}$

The significance of the Tainan Kaiyuan Temple has two aspects: its precept ordination and lectures. Chuanfang, whom many called a vinaya master (lushi 律師), engaged actively in precept-conferral since the inception of his abbotship. Seeing the decline of Taiwanese Buddhism, he collaborated with Japanese Buddhists so as to reinvigorate Taiwanese Buddhism. Vinaya Master Chuanfang's precept-conferral ceremonies included the following events—all were milestones in Taiwanese Buddhism (see Table 2):

Table 2. Master Chuanfang's precept conferral.

\begin{tabular}{|c|c|c|c|}
\hline Year & Year & Preceptor & Precepts Conferral \\
\hline 1913 & Taishō 2 & $\begin{array}{c}\text { Mt. Gu Yongquansi } \\
\text { Vinaya Master } \\
\text { Chuanfang }\end{array}$ & $\begin{array}{l}\text { Five precepts and three } \\
\text { homages (wujie sanguiyi } \\
\text { 五戒三的依) }\end{array}$ \\
\hline 1917 & Taishō 6 & Master Chuanfang & $\begin{array}{c}\text { Five precepts and three } \\
\text { homages }\end{array}$ \\
\hline 1919 & Taishō 8 & $\begin{array}{l}\text { Baizan Genshū of the } \\
\text { Myōshinji sect (still } \\
\text { under the name of } \\
\text { Master Chuanfang) }\end{array}$ & $\begin{array}{l}\text { The first conferral of } \\
\text { fourfold-assembly } \\
\text { precepts in Taiwan }\end{array}$ \\
\hline
\end{tabular}

Chuanfang, together with the Kaiyuan Temple supervisors Chengyuan and Benyuan, visited Hasegawa Jien at the Rinzai Gokokuzenji 護國禪寺 in Taipei in order to reach an agreement of collaboration. With the latter's arrangement, he paid a visit to Zen Master Genro 元魯 at the Myōshinji, Kyoto, as well as the Minister of Education (Monbu daijin 文部大臣) and the Bureau of Religions (Shūkyōkyoku 宗教局) in Tokyo (Zheng 1931, p. 31). The Sōtō lineage did not value the Tainan Kaiyuan Temple much, but Kaiyuan Temple became much more active after joining the Rinzai lineage. Likewise, the monks Chengyuan and Deyuan engaged in the South Seas Buddhist Association, which was founded in 1921 (Taishō 10). The second forum of the South Seas Buddhist Association was held at Kaiyuan Temple while Chengyuan was abbot. Deyuan was also on the committee board of the South Seas Buddhist Association, and while he was abbot collaborated with the Japanese effectively. He sent the younger generation to study at Komazawa University, including the famous figure Lin Qiuwu.

\subsection{The Zhennan Buddhist Middle School}

The Rinzai lineage built the first officially recognised Buddhist school in Taiwan: the Chinnan gakuryō (Ch. Zhennan xueliao 鎮南學寮) in Yuanshan (Taipei) established by the Rinzai leader Hasegawa Jien in 1916 was later approved by the colonial government for a name change, becoming Zhennan Buddhist Middle School (Jp. Chinnan chügakurin, Ch. Zhennan zhongxuelin) in 1917.

Initially, Hasegawa Jien, Missionary Supervisor (Jp. Bukyō kantokuchō 布教監督長) for the Rinzai lineage, and Benyuan, Abbot of Lingyun Temple, collaborated in founding the two major Buddhist institutes: Taiwan Buddhist Middle School and Zhennan Buddhist Middle School. This collaboration did not last long. Benyuan soon gave up the Sōtō Taiwan Buddhist Middle School and focused on Rinzai Zhennan Buddhist Middle School.

The Rinzai Zhennan Middle School had to rely entirely on financial support from Kyoto and obey every guideline of the Japanese home temple. This sort of conservative and dogmatic style prevented it from acquiring enough students and it was terminated four years after its creation. On the other hand, the Sōtō Taiwan Buddhist Middle School accepted ordinary students, neither focusing on monastic

10 See (Jiang 1996). Cf. (Wang 1999b, pp. 279-92). 
students nor emphasising sectarian training. It gradually became an ordinary private school, and therefore, its finances and student numbers were stable. Zhennan Middle School was abandoned and partly absorbed by the Taiwan Buddhist Middle School four years later in 1922.

\subsection{Buddhist Colleges in Southern Taiwan}

Despite the closing of the Zhennan Buddhist School, the Rinzai lineage later built other Buddhist schools and institutes, including the following (Table 3): (Zhou 2013, pp. 75-78)

Table 3. New institutes established by Rinzai leaders, 1930-1940.

\begin{tabular}{cccc}
\hline Year & Year (Japanese) & Institute Name in English & Chinese Name \\
\hline 1930 & Shōwa 5 & $\begin{array}{c}\text { Daxianyan Buddhist } \\
\text { Specialised College }\end{array}$ & $\begin{array}{c}\text { Daxianyan Fojiao } \\
\text { zhuanxiu xueyuan 大仙岩 } \\
\text { 佛教專修學院 } \\
\text { Fojiao zhuanxiu daochang } \\
\text { 佛教專修道場 } \\
\text { Linji zongjiaoshi }\end{array}$ \\
1934 & Shōwa 9 & Buddhist Specialised Centre \\
1939 & Shōwa 12 & Rinzai Priest Training Centre & $\begin{array}{c}\text { yangchengsuo 臨濟宗教師 } \\
\text { 養成所 } \\
\text { Dagangshan fojiao }\end{array}$ \\
Shōwa 14 & Dagangshan Buddhist College & $\begin{array}{c}\text { Dueyuan 大岡山佛教學院 } \\
\text { Taiwan fojiaohui nanbu } \\
\text { lianchengsuo 台灣佛教會 } \\
\text { 南部練成所 }\end{array}$ \\
\hline
\end{tabular}

Among these institutes above, the Buddhist Specialised Centre in Taipei and the South Training Centre of the Taiwan Buddhist Association in Tainan were the training centres for the Buddhist clergy, while the other three institutes were for both monastic and lay students. The curriculum of the Buddhist Specialised Centre in Taipei and the South Training Centre of the Taiwan Buddhist Association in Tainan included: Prince Shōtoku's Seventeen Article Constitution, the Diamond Sutra, the Linji Record (Ch. Linjilu, Jp. Rinzai roku 臨濟錄), the Sutra of the Brahma's Net (Ch. Fanwangjing, Jp. Bonmōkyō 梵網經), and the Guidelines of the Eight Schools (Ch. Bazong gangyao Jp. Hasshūkōyō 八宗綱要) (Jiang 2002, pp. 10-11). It is worth noticing that while the Sōtō and the Rinzai lineages were in competition most of the time, the curriculum of both schools was mostly similar.

As these schools accepted students from the north and south, respectively, the students' backgrounds were somewhat disparate. The majority of the Taiwan Buddhist Middle School was comprised of northern Taiwanese students and disciples of Master Taixu, whereas the majority of the Zhennan Buddhist Middle School was from either southern Taiwan or Yongquan Temple of Mt. Gu and Xinghua Temple of Fujian, with close connections to Tainan's Kaiyuan Temple. This indicates a different principle at work between the Sōtō and Rinzai lineages: the Rinzai lineage intended to expand its network to Chinese Buddhist circles in Fujian (Minnan 閩南). This is exactly the strategy of the Rinzai Myōshinji sect, whereas Sōtō leaders made no such moves in that direction. Nevertheless, the Sōtō lineage fared better in the educational programs and took over the Zhennan Middle School eventually.

\subsection{Tōkai Gisei's Contribution}

Overall, the Rinzai lineage relied heavily on Hasegawa Jien to build a Buddhist network in Taiwan during the Japanese occupation. There were 11 branch temples in Hasegawa's time. His successor, Amada Sakudō 天田策堂, expanded the network to 72 branch temples eight years later. Most of these branches were located in southern Taiwan.

When Hasegawa Jien and Amada Sakudō were abbots of Rinzai-ji, the famous Japanese monk Tōkai Gisei 東海宜誠 (1862-1988) was also active in creating bountiful connections in southern Taiwan (Jiang 2003; Li 1999; Shi 2008, pp. 370-85; Wang 1999b). He established Zhennan Buddhist College (Zhennan foxueyuan 振南佛學院) at Fahua Temple 法華寺, the Buddhist Specialised College (Fojiao 
zhuanxiu xueyuan 佛教專修學院) at Daxian Temple 大仙寺, and the Dagangshan Buddhist College (Dagangshan fojiao xueyuan) at Chaofeng Temple. His efforts greatly inspired Buddhists in southern Taiwan (Wang 1999a, pp. 371-72).

Tōkai Gisei also had a goal to improve nuns' education in Taiwan, and he eventually encouraged his home temple, Myōshinji, to dispatch two Japanese nuns to lead a six-month serial lecture program for female audiences at Liangfeng Temple 蓮峰寺 of Mt. Dagang in 1940 (Shōwa 15). ${ }^{11}$

\section{Pure Land Buddhist Activities in Taiwan}

\subsection{A Chaplaincy Scheme}

The Jōdo 淨土 (Pure Land) lineage became active in Taiwan later than the abovementioned Zen lineages, but they eventually built 37 branches (Jp. kōkaisho 教會所) in Taiwan (Ōhashi 1935). In all of these branches, the members actively engaged in Buddhist education, cultural promotion, youth activities, women's associations, and Sunday schools. These organisations were first advanced by Hashimoto Teitō 橋本定幢 (1858-1912). ${ }^{12}$ Below is a list of the Jōdo branches in chronological order (Table 4):

Table 4. Jōdo branches in Taiwan, $1898-1945 .^{13}$

\begin{tabular}{ll}
\hline 1. Tainan branch/Zhi'en Temple (1898) & 19. Puzijie branch/Zhengxinshan Gaoming Temple (1923) \\
2. Xinzhu branch (1899) & 20. Linluo branch (1925.12) \\
3. Danshui branch (1900) & 21. Taipei Branch Preaching Centre (1926.06) \\
4. Jilong branch/Mingzhao Temple (1902.02) & 22. Haifenglun branch (1928.07) \\
5. Zhanghua branch (1902.11) & 23. Xiluo branch (1930) \\
6. Douliu branch (1903.02) & 24. Zhushan branch (1930.06) \\
7. Ruifang branch (1904) & 25. Luodong branch (1933) \\
8. Jin'guashi Kuangshan branch (1905.6) & 26. Zhudong branch (1936) \\
9. Fengshan branch (1906) & 27. Xingang branch (1936) \\
10. Taidong branch (1913.10) & 28. Dadu branch (1939.05) \\
11. Jiayi branch (1914) & 29. Puyan branch $(1940)$ \\
12. Hualian'gang branch (1914.03) & 30. Huwei branch (1940.03) \\
13. Taizhong branch (1914.10) & 31. Yaogou branch (1940.03) \\
14. Gaoxiong branch (1914.11) & 32. Chishanyan branch (1940.03) \\
15. Yuli branch (1916.04) & 33. Baichuan branch (1940.04) \\
16. Beigang branch (1916.12) & 34. Nanhe branch (1940.11) \\
17. Linsipu branch (1917.12) & 35. Daxi branch (1941.06) \\
18. Ahou branch (1918.03) & 36. Deshan branch $(1942.11)$ \\
\hline
\end{tabular}

These branches held a variety of events for lay Buddhists, and ran all sorts of cultural activities, such as the Taiwan Business College (Taiwan shangye xueyuan 台灣商業學院), Jilong Sewing Education Centre (Jilong caifeng jiangxisuo 基隆裁縫講習所), the Jōdo Lineage Women's Association (at Preaching Centres in Taipei, Tainan, Hualian, Jilong, Beigang, Fengshan, and Pingdong), Sunday Schools (in Beigang, Taidong, Huashan, Hualian'gang), and various types of lectures. Furthermore, Takeda Kyōnin 武田興仁 established Minglun 明倫 School at Dadaocheng. Additionally, Nakajima Tatsukyō 中島達 鏡 established the Preaching Centre (Jp. Kaikyō'in, Ch. Kaijiaoyuan 開教院) in Tainan. ${ }^{14}$ Among these institutes, only the Taiwan Business College remains active in the present day, under the new name of Nanying Vocational School (Nanying gaoji shanggong zhiye xuexiao 南英高級商工職業學校). ${ }^{15}$ The Jōdo

11 Details will be discussed at the fourth section of this paper.

12 See (Matsukane 1999).

13 Cf. (Shi 2008, pp. 415-27).

14 Some hold that this institute was built by Mizusawa Eitai 水澤永泰 in Zhanghua. See Taiwan jiaoyu yan'gezhi (Xu 2010, p. 998).

15 It was formerly the Tainan Xuetang 台南學堂, renamed Taiwan Business College (Taiwan shangye xueyuan 台灣商業學院) by Ishibashi Eku 石橋慧空 in 1924, and was turned into an ordinary private college. It was reformed in 1950 after the Japanese government left Taiwan and later became the Nanying Vocational School. 
lineage demonstrated a high level of integration between monastics and the laity and rather intensive engagement in social welfare.

In 1905 (Meiji 35), the Nishi Honganji sect of Jōdo Shinshū built the Pure Land Tainan Education Centre (Jp. Jödoshū Tainan Kaikyō'in, Ch. Jingtuzong Tainan kaijiaoyuan 淨土宗台南開教院) as a monastic training centre. They also built the Centre for Taiwanese Buddhist Chaplaincy (Jp. Taiwan bukkyōshi yōseisho, Ch. Taizwan fojiaoshi yangchengsuo 台灣佛教師養成所) in Taipei in 1940 (Shōwa 15). Similarly, the Ōtani sect of Jōdo Shinshū established the Monastic Training Centre for Taiwanese monastics (Jp. Taiwan hondōjin sōryo yōseisho, Ch. Taiwan bendaoren senglu yangchengsuo 台灣本島人僧侶養成所) in Taipei in 1940 (Jiang 2002, pp. 10-11).

\subsection{The Aboriginal Area}

Missionary work in the aboriginal areas was mainly carried out by the Honganji sect. ${ }^{16}$ Shiun Genhan 紫雲玄範, a well-known Honganji chaplain, signed an alliance treaty (Taiwan kaikyō dōmei 台灣 開教同盟) with Hashimoto Teitō after he stayed in Taiwan for one year beginning in 1868 (Meiji 1). The non-tolerance policy starting from 1913 (Taishō 2), however, aimed to suppress local religious groups, so Shiun Genhan's missionary plan for the aboriginal areas had to be interrupted for a while. Yet it did not completely cease until a time after World War II, when the Honganji sect gradually moved activities away from Taiwan.

To sum up, the Honganji sect developed in Taiwan from 1915 (Taishō 4). After the Xilai'an Temple Incident, many Taiwanese Zhaijiao followers joined the Japanese Pure Land lineage so as to better cope under the high pressure of government control. ${ }^{17}$ Before World War II, especially between 1917 and 1923, arrangements were still made to educate Taiwanese Buddhist leaders, such as sending the chaplain Wang Zhaolin 王兆麟 (1887-1963) from Gaoxiong to study for one year at Bukkyō University, Kyoto. ${ }^{18}$ Wang Zhaolin was active for a short while after returning to Taiwan before World War II. He was especially active at the Mituo Chan Temple, Tainan. Unfortunately, after the severe Great Depression in the global economy, Honganji's financial condition became rather tight and limited; it became increasingly difficult to keep overseas Buddhist institutions. Taiwan was no exception.

\section{Taiwanese Monks and Nuns in Japan}

One direct influence of the above Japanese sects on Taiwanese monastic education is the remarkable number of Taiwanese monastics who studied in Japan. The Sōtō lineage had been a prominent supporter for hosting Taiwanese students. ${ }^{19}$ This trend continued for several generations; representative figures are as below (Table 5):

On this list, Meditation Master Derong 德融 (1884-1977) was the first monk from Taiwan to study in Japan, and he did so under the instruction of Ishikawa Sodō 石川素童, entering the Sōtō First High School in 1909 (Meiji 42). Derong was an important disciple of Shanhui. Upon his return to Taiwan, he assisted Shanhui in establishing the Lingquansi Buddhist College (Lingquansi foxueyuan 靈泉寺佛學 院) at the Lingquan Temple of Mt. Yuemei in 1923 (Taishō 12). It had successful enrollment between 1924-1926, and he started the Meditation College (Chanlin xueyuan 禪林學院), which continued for three years from 1941 (Shi 2003, pp. 178-79).

16 Regarding the Japanese chaplaincy in the aboriginal area, see (Fan 1999, pp. 253-79). The following part of the current paper concerning Japanese Buddhism in the aboriginal area largely consults Fan's work. For further information of the historical background, see (Kan 2011, pp. 102-14).

17 The Xilai'an Temple Incident stirred up political debates and identity conflicts; on this issue, see (Jiang 1999, pp. 245-59; Wang and Li 1999, pp. 29-67).

18 For a further study on Wang Zhaolin, see (Kan 2014b).

19 Ōno Ikuko has a detailed study on the Taiwanese students at Komazawa University, see (Ōno 2009). 
Table 5. Taiwanese monks and nuns who studied in Japan.

\begin{tabular}{|c|c|c|c|}
\hline & Affiliation in Taiwan & $\begin{array}{l}\text { Hosting Institute } \\
\text { in Japan }\end{array}$ & Japanese Supervisor \\
\hline Derong & $\begin{array}{l}\text { Lingquan Temple of Mt. } \\
\text { Yuemei, Jilong }\end{array}$ & $\begin{array}{l}\text { Sōtōshū daiichi chūgakurin } \\
\text { 曹洞宗第一中學林 }\end{array}$ & Ishikawa Sodō \\
\hline Delin & $\begin{array}{l}\text { Lingquan Temple of Mt. } \\
\text { Yuemei, Jilong }\end{array}$ & Komazawa University & Nukariya Kaiten \\
\hline Zhengfeng (Lin Qiuwu) & Tainan Kaiyuan Temple & Komazawa University & Nukariya Kaiten \\
\hline Zhengguang (Gao Zhide) & Tainan Kaiyuan Temple & Komazawa University & Nukariya Kaiten \\
\hline Shengguang 勝光 (nun) & Yongxiu jingshe, Xinzhu & $\begin{array}{c}\text { Kansai amanogakurin 關西 } \\
\text { 尼學林 }\end{array}$ & \\
\hline Zhengding 正定 (nun) & Yongxiu jingshe, Xinzhu & Kansai amanogakurin & \\
\hline Shengguang 聖光 (nun) & Pilu Chan Temple & Kansai amanogakurin & \\
\hline Zhengguo 正果 (nun) & Pilu Chan Temple & Kansai amanogakurin & \\
\hline Daxian 達賢 (nun) & Yuantong Chan Temple & Kansai amanogakurin & \\
\hline Lianzhou 蓮舟 (nun) & Yuantong Chan Temple & Kansai amanogakurin & \\
\hline Ruxue 如學 (nun) & Fayun Temple, Dahu & $\begin{array}{l}\text { Kansai amanogakurin; } \\
\text { Komazawa University }\end{array}$ & Sawaki Kōdō 木興道 \\
\hline
\end{tabular}

The nuns above were mostly from the Xinzhu and Taipei area. Moreover, all of these nuns came from temples associated with the Fayun Temple, Dahu (Xinzhu). We will examine the connection between these temples in the later part of this article.

Towards the end of the Japanese occupation, the Taiwanese monks and nuns who returned from Japan became capable of running their own Buddhist colleges in Xinzhu and Taipei. The tendency to study in Japan was particularly well accepted by Taiwanese Buddhists in northern Taiwan and it did not cease after the Japanese army left Taiwan at the end of World War II.

\section{Taiwanese Nuns}

\subsection{SSBA Lectures and the Xinzhu Temple}

The growth of self-esteem and recognition of Taiwanese nuns was directly due to the beneficent Japanese educational activities. An important resource was the abovementioned South Seas Buddhist Association, which held 19 Buddhist lectures between 1921 and 1936, as well as lectures exclusively for female audiences. Those lectures for female followers include the following (Wu 2007, p. 376):

(1) 1924 (Taishō 13): the Taipei Branch of Honganji.

(2) 1925 (Taishō 14): the Yishantang 一善堂of Xiangshan, Xinzhu.

(3) 1928 (Shōwa 3): the Mituo Chan Temple, Tainan.

The three lectures above for female followers had a profound impact on Taiwanese Buddhism. The abovementioned Jōdo and Rinzai lineages mostly emphasised contents of Japanese Buddhism, so as to enhance Taiwanese understanding of Japanese Buddhism. There was also an emphasis on the Pure Rules (qinggui 清規), codes of monastic discipline and ritual, in order to "rectify" Taiwanese monasticism.

In 1936 (Shōwa 11), a Buddhist lecture was held at Xinzhu, not by the South Seas Buddhist Association, but by an active Xinzhu Temple 新竹寺, which attracted 20 male and 23 female participants. The lecture series at Xinzhu Temple included an introduction to Japanese Buddhist sects, the Heart Sutra, meditation, Zen studies, Shintō religion, etc. ${ }^{20}$ It is interesting to note that females in the audience outnumbered males, which indicates an increasing female participation and demand for knowledge of Buddhism among the laity and monastics. The female participants of this lecture included famous nuns, such as Miaohang 妙航, Daguang 達光, Ruxue 如學 (1913-1992), and Shanzhi 善治, who all became very influential in Taiwan later on. In other words, the timely support that the Japanese brought into Taiwan suitably guided these young and energetic nuns.

20 Nanying fojiao Vol. 14, No. 12 (1936), p. 46. 


\subsection{Master Jueli}

A prime figure in promoting the education for female monastics is Chan Master Jueli 覺力 (1881-1933) from Yongquan Temple of Mt. Gu, Fujian Province (Shi 1997, pp. 148-49; D. Shi 1999). Following Shanhui and Derong's efforts in establishing Buddhist colleges, Miaoguo 妙果 (1884-1963) invited his master Jueli from Fujian to Taiwan to educate Taiwanese Buddhists. He arrived in Taiwan in 1909 and was soon affiliated with the Sōtō lineage and received a Japanese monk's certificate.

Particularly interesting is the Fayun Temple community, founded by Jueli. After Master Jueli established Fayun Temple in 1913, female disciples at this temple comprised the largest number of female disciples at any temple in Taiwan. By proposing approval and receiving it by the SSBA, Master Jueli hosted a six-month lecture program for female followers at Xiangshan Yishantang, Xinzhu in 1925, as just mentioned in the previous section. ${ }^{21}$ A significant fact is that there were four female lecturers, which was rare in Taiwan. The news in the Nanying fojiao recorded this event and the names of the four female lecturers. ${ }^{22}$

Later on, Master Jueli participated in building several other female educational institutes, such as the Buddhist Study Group (Foxue yanjiushe 佛學研究社) of Fayun Temple and the Academy of Guanyinshan (Guanyinshan yanjiuyuan 觀音山研究院). He also assisted a female disciple Miaoqing 妙 清 (1911-1955) in building the Yuantong Chan Temple in Zhonghe (Taipei). Likewise, he helped his female disciple Miaochen 妙鹿 (1887-1954) establish Pilu Temple 毗盧寺 in Houli (Taizhong). Jueli was particularly proud of these two nunneries. The Yuantong Chan Temple, in particular, attracted almost 100 female followers to its summit. ${ }^{23}$ I call all the above institutes members of a 'Fayun Temple community' in the current paper, including: Fayun Temple, Yitong Temple (Yishangtang), Yuantong Chan Temple, and Pilu Temple. All of these institutions that Jueli funded or assisted in funding played an important role in nuns' education in Taiwan (Shi 2009, pp. C1-4; Su 2015). Jueli's efforts turned Fayun Temple and the Xinzhu area into a cradle for female Buddhist education: the earliest five nuns who studied in Komazawa University were all from this Fayun Temple community (Ōno 2009, p. 95). Furthermore, during Jueli's time, 20 female students studied in Japan, and 12 of them came from the Fayun Temple community (Wang 2014).

\subsection{Female Education in Southern Taiwan}

The achievements of nuns in Taiwan have become a main feature of Taiwanese Buddhism. Japanese temples, in addition to their other functions, also became Buddhist centres for educating nuns. The Linquan Temple of Mt. Yuemei in northern Taiwan and Chaofeng Temple of Mt. Dagang in southern Taiwan both flourished under the guidance of Japanese Zen lineages, i.e., Sōtō and Rinzai (H. Shi 1999, p. 258). These Zen Buddhist temples in Taiwan organised serial lectures for female followers. Important bases for this included the abovementioned Liangfeng Temple of Mt. Dagang (Rinzai), Lingquan Temple of Mt. Yuemei (Sōtō), and Fayun Temple of Dahu (Sōtō).

Particularly noteworthy is that the Sōtō lineage held a six-month serial lecture in 1925, open to both male and female followers, at Lingquan Temple of Mt. Yuemei. Similarly, the Myōshinji sect of the Rinzai lineage also sent two Japanese nuns, Sawaki Kōdō 澤木弘道 and Tōkai Shōdō 東海昌道, to Lianfeng Temple of Mt. Dagang to lead a six-month serial lecture in 1940. This act proves that the Japanese main temple of the Rinzai lineage valued this Mt. Dagang nunnery; the Lianfeng Temple was at that time the most famous nunnery in Taiwan. The curriculum included language education, chanting and recitation of Buddhist scriptures, meditation, the history of Buddhism, monastic regulations, and

21 The Yishantang was originally a Zhaitang, aka. a branch of the Zhaijiao religion. After meeting Master Jueli, the lay female owner Jueming 覺明 converted to Buddhism and then renamed it as Yitong Temple 一同寺.

22 Nanying fojiao, Vol. 3, No. 4 (1925). Also see a discussion on the significance of this event in (Su 2015, p. 41).

23 This information was conveyed from an oral conversation with Ven. Xinghong 性宏, the current abbot of Yuantong Chan Temple on November 22, 2019. 
sewing. ${ }^{24}$ These courses were mostly identical with what was offered at Japanese nunneries. The instruction language in Taiwan was Japanese, an intentional decision aiming to elevate Taiwanese nuns' Japanese language levels. These two nuns gave lectures in Taiwan continuously, until the time when the Japanese colonial government stepped down. Tōkai Shōdō thereupon left Taiwan with the Japanese army. In contrast, Sawaki Kōdō decided to stay and applied for Taiwanese residency, residing in Pingdong.

One of the established Buddhist colleges, the Fayunsi Buddhist College founded by Master Jueli, saw in this period several of its respected nuns go to Japan for study. Upon their return to Taiwan, they played important roles. Meanwhile, Tōkai Gisei, representing the Rinzai lineage, set up the Dagangshan Buddhist College at Chaofeng Temple.

The Chaofeng Temple was closely connected to the Dongshan Temple in Pingdong, the former Rinzai Pingdong branch from 1925. The Dongshan Temple played an important role in nuns' education in Taiwan. The first director of the Dongshan branch was Tōkai Gisei, and Chen Quanjing 陳銓淨 was second. It was renamed Dongshan Chan Temple in 1936. Sawaki Kōdō and Tōkai Shōdō moved there in 1942. After World War II, Shi Yuanrong 釋圓融 from Mt. Dagang Longhu'an 龍湖庵 Nunnery moved there to look after the temple, and from then on, Dongshan Chan Temple gradually became a nunnery. This important nunnery nourished a remarkable number of influential nuns in Taiwan. The well-known disciples of Yuanrong included Tianyi 天乙, Tianji 天機, and Tianchan 天禪. Tianyi then had an outstanding disciple, Wuyin 悟因, who founded the Luminous Nunnery (Xiangguang nisengtuan 香光尼僧團). Many of these female disciples went to study in Japan. Beginning with Tōkai Gisei inviting Sawaki Kōdō and Tōkai Shōdō to give the six-month course at Liangfeng Temple Temple, and leading up to the time of Yuanrong's arrival, nuns' education in Taiwan greatly advanced.

\section{Concluding Remarks}

Overall, during the Japanese occupation of Taiwan, the Japanese lineage most influential to Buddhist education in Taiwan was the Sōtō lineage, its activities mostly occurring in Taipei. Most major temples in Taipei were affiliated with the Sōtō lineage. The Jōdo shinshū was the most influential lineage in lay education as well as aboriginal activities. As for the Rinzai lineage, their main area of influence was in southern Taiwan, with Tainan Kaiyuan Temple as its main centre. The other lineages came later to Taiwan. Gradually, these Japanese Buddhists reached out to Taiwanese residents. Among the Japanese Buddhist educational institutes in Taiwan, the most developed institution was Sōtō's Taiwan Buddhist Middle School, and the second was Rinzai's Zhennan Buddhist Middle School. Both were initiated by Taiwanese monks in collaboration with Japanese Buddhists. Judging by the outcomes of history, this collaboration model was not always successful when encountering the interference of politics. In contrast to the tension between the Sōtō and the Rinzai Buddhist Middle Schools that were in competition most of the time, the South Seas Buddhist Association used specially scheduled seminars and lectures to provide resources for education. Despite being less structured than the Buddhist Middle Schools, this model indeed encouraged Buddhist learning in Taiwan. The Pure Land lineage began its activities later than the other two, but caught up rapidly under the efficient management of Hashimoto Teitō. Thirty-seven branches were built to conduct lay Buddhist education, youth programs, women's associations, and Sunday schools. Achievements of the Pure Land lineage in Taiwan included operating the well-known Taiwan Business College and the Minglun School, and various undertakings in aboriginal areas. While one sees that the Japanese Zen and Pure Land communities tend to adopt different approaches to their monasticism and monastic education, all of these lineages established institutions for monastic education, as well as lay educational programs given by monastics. The Japanese models strengthened lay-monastic interaction through Buddhist education in Taiwan during the Colonial Period.

24 Nanying fojiao Vol. 18, No. 8 (1940), p. 33. 
After World War II, together with the great economic depression, Honganji's finances were downgraded and it gradually stopped its activities in Taiwan. Likewise, other Japanese sects had financial issues, such that overseas activities became more difficult. After the Nationalist Party arrived to Taiwan, the shift of political power made Japanese activity in Taiwan much more difficult. These were the factors confining the development of Japanese Buddhism in Taiwan. One should be reminded that the mainland connection, primarily that of Yongquan Temple on $\mathrm{Mt}$. Gu, was never interrupted during the Japanese occupation of Taiwan. For these reasons, it was easier for Taiwanese Buddhists to cut off the Japanese ties after the World War II.

Development of the education of Taiwanese nuns is an important feature of Taiwanese Buddhism. During the Japanese occupation, Taiwanese Buddhist communities that developed under Japanese guidance were mainly Lingquan Temple on Mt. Yuemei and Dahu Fayun Temple. The latter temple, under the leadership of Abbot Jueli, attracted a great number of female sangha members. Similarly, the Chaofeng Temple on Mt. Dagang was the most vigorous Buddhist hub in southern Taiwan. The Rinzai lineage's Myōshinji sect sent two Japanese nuns to deliver lectures at the Chaofeng Temple for six months. The arrival of Sawaki Kōdō and Tōkai Shōdō at the Chaofeng Temple paved the way for the remarkable development of the Dongshan Chan Temple, where the nun Yuanrong nurtured numerous female disciples. Taiwanese monastics who studied in Japan included both monks and nuns. The continuity of Japanese Buddhist traditions in Taiwan and the enduring presence of active female participation in Taiwanese Buddhism suggests the need for further research on later periods. It is at least evident that models for education and the emphasis on monastic education began with the Japanese schools.

The religious policies of the colonial government shaped the direction of Buddhist education in Taiwan during this period of Japanese occupation. After the Xilai'an Incident, the Japanese government became more controlling and the South Seas Buddhist Association was established so as to re-educate Taiwanese Buddhists. After the Marco Polo Bridge Incident, more intense control of local Taiwanese temples was carried out, resulting in further integration between Japanese Buddhism and Taiwanese communities. Furthermore, while the Japanese sects supported Taiwanese Buddhist communities of practitioners, an obvious pattern of regional difference occurred: the Sōtō lineage concentrated its activities in the North, whereas the Rinzai lineage did so in the South. The Pure Land lineage, in contrast, spread out to aboriginal villages all over the island. This paper cannot exhaustively represent the complex picture of Taiwanese Buddhism during the Japanese occupation, but it can serve as part of the foundation of knowledge for further study on Taiwanese, Chinese, and even East Asian Buddhism, during this pivotal historical period.

Funding: This research was funded by the Taiwan Ministry of Science and Technology (grant number: 108-2410-H-030-084-).

Conflicts of Interest: The author declares no conflict of interest.

\section{References}

Birnbaum, Raoul. 2007. The Deathbed Image of Master Hongyi. In The Buddhist Dead: Practices, Discourses, Representations. Edited by Jacqueline Stone and Bryan Cuevas. Honolulu: University of Hawai'i Press, pp. 175-207.

Chen, Bing 陳兵, and Zimei Deng 鄧子美. 2003. Ershi shiji zhongguo fojiao 二十世紀中國佛教. Taipei: Xiandaichan chubanshe. First published 2000.

Clart, Philip, and Charles Jones, eds. 2003. Religion in Modern Taiwan. Honolulu: University of Hawai'i Press.

Fan, Chunwu 范純武. 1999. Riben fojiao zai rizhi shiqi Tawan fanjie de bujiao shiye-yi zhenzong benyuansi pai wei zhongxin de kaocha 日本佛教在日治時期台灣蕃界的佈教事業一以真宗本願寺派為中心的考察. Yuan Kuang Journal of Buddhist Studies [Yuangang xuebao] 4: 253-79.

Goodell, Eric. 2008. Taixu's Youth and Years of Romantic Idealism, 1890-1914. Chung-Hwa Buddhist Journal 21: 77-121. 
De Groot, J. J. M. 1903-1904. Sectarianism and Religious Persecution in China, a Page in the History of Religions. Amsterdam: J. Miller.

Hammerstrom, Erik. 2015. The Science of Chinese Buddhism: Early Twentieth-Century Engagements. New York: Columbia University Press.

Hou, Kunhong 侯坤宏. 2018. Taixu shidai: duowei shijiaoxia de minguo fojiao (1912-1949) 太虛時代 : 多維視角下的民 國佛教 (1912-1949). Taipei: Zhengda chubanshe.

Huang, Julia. 2009. Charisma and Compassion: Cheng Yen and the Buddhist Tzu Chi Movement. Cambridge: Harvard University Press.

Ji, Zhe. 2015. Buddhist Institutional Innovations. In HO4, Modern Chinese Religion II: 1850-2015. (Handbook of Oriental Studies. Section 4 China). 2 vols. Edited by John Lagerwey, David Ownby, Zhe Ji and Vincent Goossaert. Leiden, The Netherlands: Boston, Massachusetts: Koninklijke Brill, Vol. 2, pp. 729-66.

Ji, Zhe, and Philip Liddell. 2005. The Establishment of a Lay Clergy by the Modern Chan Society: Some Logics in the Field of Modern Chinese Buddhism. China Perspectives 59: 56-65.

Jiang, Canteng 江燦騰. 1996. Taiwan fojiao bainianshi zhi yanjiu 臺灣佛教百年史之究: 1895-1995. Taipei: Nantian chubanshe.

Jiang, Canteng. 1999. Guanyu Taiwan jinxiandai fojiao de yanjiu jingyan yu pipan yishi dakewen 關於台灣近現代 佛教的研究經驗與批判意識答客問. Si yu yan 思與言 37: 245-59.

Jiang, Canteng. 2001. Riju shiqi Taiwan fojiao wenhua fazhanshi 日據時期臺灣佛教文化發展史. Taipei: Nantian chubanshe.

Jiang, Canteng. 2002. Taiwan jindai fojiao jiaoyu yange 台灣近代佛教教育沿革. In Taiwan foxue yuansuo jiaoyu nianjian 台灣佛學院所教育年鑑. Taipei: Zhonghua foyansuo.

Jiang, Canteng. 2003. Rizhi shiqi Gaoxiung fojiao fazhan yu Donghai Yicheng 日治時期高雄佛教發展與東海宜誠. The Journal of Chinese Buddhist Studies (JCBS) [Zhonghua foxue xuebao] 16: 211-31.

Jiang, Canteng, and Jianchuan Wang 王見川, eds. 1994. Taiwan zhaijiao de lishi guancha yu zhanwang: shoujie Taiwan zhaojiao xueshu yantaohui lunwenji 台灣齋教的歷史觀察與展望: 首屆台灣齋教學術討會論文集. Taipei: Xinwenfeng chubanshe.

Jones, Charles Brewer. 1999. Buddhism in Taiwan: Religion and the State, 1660-1990. Honolulu: University of Hawai'i Press.

Kan, Cheng-tzung 閔正宗. 1999. Taiwan fojiao yibainian 臺灣佛教一百年. Taipei: Dongda chubanshe.

Kan, Cheng-tzung. 2011. Taiwan rishi shiqi fojiao fazhan yu huangminhua yundong-huangguo fojiao de lishi jincheng 臺 灣日治時期佛教發展與皇民化運動一「皇國佛教」的歷史進程. Taipei: Boyang chubanshe.

Kan, Cheng-tzung. 2013. Riben zhimin shiqi reseng zai Mengjia Longshansi de huodong-yi Zuozuomu Zhenlong ji Caodongzong weili (1895-1901) 日本殖民時期日僧在艋舺龍山寺的活動 一以佐佐木珍龍及曹洞宗為例. Yuan Kuang Journal of Buddhist Studies [Yuangang xuebao] 33: 198-222.

Kan, Cheng-tzung. 2014a. Taiwan fojiao se zhimin yu hou zhimin 臺灣佛教的殖民與後殖民. Taipei: Boyang chubanshe.

Kan, Cheng-tzung. 2014b. Zhimin fojiao de rentong yu zhanhou zhuanxiang-Wang Zhaolin de kuazhengquan hongfa shiye 殖民佛教的「認同」與戰後「轉向」一王兆麟的跨政權弘法事業. [The Identity of Colonial Buddhism and its Shift after World War II: Wang Zhaolin's Propagation of Buddhism across the Two Regimes]. Xuanzang Foxue yanjiu 玄奘佛學研究 21: 29-60.

Li, Shiwei 李世偉. 1999. Riju shiqi Zhong Tai fojiao jiaoliu luelun 日據時期中、台佛教交流略論. Yuan Kuang Journal of Buddhist Studies [Yuanguang foxue xuebao] 3: 293-304.

Li, Yuzhen 李玉珍. 2016. Zhanhou Taiwan fojiao yu nuxing 戰後臺灣佛教與女性. New Taipei City: Boyang chubanshe.

Madsen, Richard. 2007. Democracy's Dharma: Religion Renaissance and Political Development in Taiwan. Berkeley and Los Angeles: University of California Press.

Matsukane, Kimimasa 松金公正. 1999. Guanyu riju chuqi Riben fojiao cojung bujiaoshi de huodong一yi jingtuzong bujiaoshi Qiaoben Dingchuang Zaidu rizhi weili 關於日據初期日本佛教從軍佈教使的活動-以淨土宗佈教使 橋本定幢《再渡日誌》為例. Yuan Kuang Journal of Buddhist Studies [Yuanguang foxue xuebao] 3: 383-421.

Minowa, Kenryō 蓑輪量. 2003. Gendai taiwan bukkyō ni okeru shitei no ikusei ni tsuite 現代台教師弟育成. Ningen bunka: Aichi gakuin daigaku ningen bunka kenkyūsho kiyō 人間文化：愛知院大人間文化研究所紀要 18: 69-83.

Minowa, Kenryō. 2006. Taiwan no gendai bukkyō 台現代教. Paligaku Bukkyō bunkagaku 教文化 20: 1-21.

Nakanishi, Naoki 中西直樹. 2016. Shokuminchi taiwan to nihon bukkyō 植民地台日本教. Kyoto: Sanninsha. 
Ōhashi, Sutesaburō 大橋捨三郎. 1935. Shinshū honpa honganji Taiwan kaikyōshi 真宗本派本願寺臺灣開教史. Taipei: Shinshū honpa honganji Taiwan betsuin.

Ōno, Ikuko 大野育子. 2009. Rizhi shiqi fojiao jingying de jueqi-yi caodongzong juze daxue Taiwan liuxuesheng wei zhongxin 日治時期佛教菁英的崛起-以曹洞宗駒澤大學台灣留學生為中心 (The Appearance of the Buddhism Elites in the Japanese Taiwan Rule Times by Overseas Taiwanese Students of Sōtō Zen Buddhism Komazawa University). Master's dissertation, Tamkang University History Department, Taipei, Taiwan.

Payne, Richard K., and Kenneth K. Tanaka, eds. 2004. Approaching the Land of Bliss: Religious Praxis in the Cult of Amitäbha. Honolulu: University of Hawai'i Press.

Rintzinger, Justin. 2017. Anarchy in the Pure Land: Reinventing the Cult of Maitreya in Modern Chinese Buddhism. Oxford: Oxford University Press.

Shi, Chanhui 釋禪慧. 1997. Jueli chanshi nianpu 覺力禪師年譜. Taipei: Sanhui jiangtang.

Shi, Daocheng 釋道成. 1999. Jueli chanshi jiqi paixia yanjiu 覺力禪師及其派下研究. Master's thesis, Yuanguang Buddhist College, Taipei, Taiwan.

Shi, Huiyan 釋慧嚴. 1998. Riben caodongzong yu Taiwan fojiao senglu de hudong 日本曹洞宗與台灣佛教僧侶的 互動. The Journal of Chinese Buddhist Studies (JCBS) [Zhonghua foxue xuebao 中華佛學學報] 11: 119-53.

Shi, Huiyan. 1999. Cong taiminri fojiao de hudong kan niseng zai Taiwan de fazhan 從台閩日佛教的互動看尼僧 在台灣的發展. The Journal of Chinese Buddhist Studies (JCBS) [Zhonghua foxue xuebao] 12: 249-74.

Shi, Huiyan. 2003. Zaijianshi rizhi shidai Taiwan fojiaojie congshi de jiaoyu shiye 再檢視日治時代台灣佛教界從事 的教育事業. The Journal of Chinese Buddhist Studies (JCBS) [Zhonghua foxue xuebao] 16: 169-210.

Shi, Huiyan. 2008. Taiwan yu minri fojiao jiaoliushi 台灣與閩日佛教交流史. Gaoxiong: Chunhui chubanshe.

Shi, Huiyan. 2009. 1945 nian qian niseng jiaoyu de shikuang 1945年前尼僧教育的實況. In 2009 fojiao sengqie jiaoyu guoji yantaohui-xiandai nisengqie jiaoyu de huigu yu qianzhan 2009佛教僧伽教育國際研討會一現代尼僧伽教育 的回顧與前瞻. Taipei: Longshansi.

Su, Mei-Wen 蘇美文. 2015. Shi yiqie nuzi tongqu zhengjue: riju shiqi Jueli fashi dui fojiao nuxing jiaoyu zhi tuidong使一切女子同取正覺：日據時期覺力法師對佛教女性教育之推動. Journal of China University of Science and Technology [Zhonghua keji daxue tongshi jiaoyu xuebao] 6: 37-76.

Tainaka, Chizuru 胎中千鶴. 2008. Sōgi no chikuminchi shakaishi: teikoku nihon to Taiwan no "kindai" 葬儀植民地社史: 帝日本台「近代」. Tokyo: Fukyosha.

Tsukamoto, Zenryū 塚本善隆. 1949. Rakyō no seiritsu to ryūden ni tsuite羅教成立流傳. Journal of Oriental Studies [Tōhō gakuhō] (Kyoto) 17: 11-34.

Wang, Jianchuan 王見川. 1999a. Luelun riseng Donghai Yicheng jiqi zaitai zhi fojiao shiye 略論日僧東海宜誠及其 在臺之佛教事業. Yuan Kuang Journal of Buddhist Studies [Yuanguang foxue xuebao] 3: 357-82.

Wang, Jianchuan 王見川. 1999b. Luelun riju shiqi de Tainan Kaiyuansi 略論日據時期的台南開元寺. Yuan Kuang Journal of Buddhist Studies [Yuanguang foxue xuebao] 4: 279-92.

Wang, Jianchuan 王見川, and Shiwei Li 李世偉. 1999. Riju shiqi Taiwanfojiao de rentong yu xuanze一yi zhongtai fojiao de jiaoliu wei shijiao 日據時期台灣佛教的認同與選擇—以中台佛教的交流為視角. In Taiwan de zongjiao yu wenhua. Taipei: Fuyang wenhua chubanshe, pp. 29-67.

Wang, Xuanping 王宣蘋. 2014. Rizhi shiqi liuxue riben de niseng 日治時期留學日本的尼僧. MA dissertation, Taiwan Normal University. Institute of History of Taiwan, Taipei, Taiwan.

Washimi, Sadanobu 熟見定信. 1985. Jōdoshū no taiwan fukyō 土宗台布教. Bukkyō bunka kenkyū 教文化研究 30: 101-17.

Welch, Holmes. 1967. The Practice of Chinese Buddhism, 1900-1950. Cambridge: Harvard University Press.

Welch, Holmes. 1968. The Buddhist Revival in China. Cambridge: Harvard University Press.

Welch, Holmes. 1972. Buddhism under Mao. Cambridge: Harvard University Press.

Wen, Guoliang 温國良. 1999. Riju chuqi riben zongjiao zai tai bujiao gaikuang一yi zongdufu minzhengbu diaocha wei zhongxin日據初期日本宗教在臺布教概況一以總督府民政部調查為中心. Taiwan wenxian 臺灣文獻 50: 211-31.

Wu, Minxia 吳敏霞. 2007. Riju shiqi de Taiwan fojiao 日據時期的台灣佛. Taizhong: Taiping Ciguangsi.

Xiqing Xu 許錫慶, trans. 2010, Taiwan jiaoyu yangeshi 臺灣教育沿革誌. Taipei: The Taiwan Historica [Guoshiguan Taiwan wenxianguan], From Japanese: Taiwan kyōiku engakushi, Edited by the Ministry of Taiwan, Taipei.

Yan, Shangwen 顔尚文, ed. 2008. Taiwan fojiao yu hanren chuantong xinyang yanjiu 臺灣佛教與漢人傳統信仰研究. Jiayi: The Taiwan Institute for the Humanities, National Chung Cheng University.

Zeng, Jinglai 曾景來. 1937. Kaiyuan chansi jilue 開元禪寺記略. Nanying fojiao 15: 39-42. 
Zheng, Zhuoyun 鄭卓雲. 1931. Taiwan Kaiyuansi shamen liezhuan-Chuanfang heshang 台灣·開元禪寺沙門列 傳一傳芳和尚. Nanying fojiao 9: 29-33.

Zhou, Yuru 周玉茹. 2013. Taiwan fojiao de sengqie jiaoyu: yi foxueyuan wei zhongxin 台灣佛教的僧伽教育: 以佛學院 為中心. Taizhong: Taiping Ciguangsi. 